Available online at http://www.anpad.org.br/bar

\title{
Scholarly Management Knowledge in the Periphery: Argentina and Brazil in Comparative Perspective (1970-2005)
}

\author{
Ernesto R. Gantman * \\ E-mail address: ernesto.gantman@comunidad.ub.edu.ar \\ Universidad de Buenos Aires and Universidad de Belgrano \\ Buenos Aires, Argentina.
}

\begin{abstract}
This paper examines academic management knowledge in two developing countries, Argentina and Brazil. It shows that the level of scholarliness of this type of knowledge varies greatly within countries with a similar degree of economic development. Furthermore, the paper demonstrates that the main factor behind the expansion of scholarly management knowledge in the countries under study is the institutionalization of the academic community through faculty professionalization, which is in turn influenced by the size of the economy and the state's commitment to supporting the higher education system.
\end{abstract}

Key words: management knowledge; business education; Latin America; Argentina; Brazil.

Copyright (C) 2010 Brazilian Administration Review. All rights reserved, including rights for translation. Parts of this work may be quoted without prior knowledge on the condition that the source is identified.

\footnotetext{
* Corresponding author: Ernesto R. Gantman

Escuela de Economía y Negocios Internacionales, Universidad de Belgrano, M.T. de Alvear 1560 (1060), Buenos Aires, Argentina.
} 


\section{INTRODUCTION}

In the last decade, there has been growing academic interest in the study of the production, diffusion and consumption of management knowledge (Alvarez, 1998; Sahlin-Andersson \& Engwall, 2002). The literature has mainly adopted a neoinstitutionalist approach to map the configuration of an organizational field constituted by diverse individual and collective actors who participate in the construction of management knowledge. Several studies helped to advance our knowledge of the different components of this organizational field, such as consulting firms (Engwall \& Kipping, 2003), academia (Augier, March, \& Sullivan, 2005) and business schools (Engwall, 2007). However and with few exceptions (e.g., Alvarez, Enrione, \& Mazza, 1997; Ibarra-Colado, 2006; Üsdiken \& Çetin, 2001), these studies have dealt exclusively with developed countries. Thus, and despite recent calls for comparative research aimed at furthering our understanding of how different historical and geographic environments frame the genesis and circulation of management knowledge (Sahlin-Andersson \& Engwall, 2002), there is still a significant void of theoretical reflection and empirical analysis on the characteristics of these processes in peripheral or less developed countries [LDCs].

Perhaps this is due to the fact that the participation of researchers from LDCs in international - i.e., Anglo-Saxon - scholarly journals is virtually nil (Baruch, 2001), which could suggest that such countries are mere marginal players in the game of management knowledge production. Their role seems restricted to importing knowledge (Ibarra-Colado, 2006; Üsdiken \& Çetin, 2001) and imitating the most superficial, and therefore easily replicable, features of the business schools patterned after the American model (Alvarez et al., 1997). But actually, local production of management knowledge is indeed generated in many LDCs, and little research has been done to examine its characteristics.

The preceding considerations show the academic relevance of analyzing what type of administrative knowledge circulates in these countries in order to establish how economic, political and institutional conditions affect its production and diffusion. This research aims to further our understanding of the development of management knowledge in LDCs with a comparative analysis of the production of scholarly management knowledge in Argentina and Brazil. These countries were chosen for several reasons, particularly the fact that both have a similar level of economic development - middle income economies, according to the World Bank country classification - and common cultural traditions inherited from their Iberian colonial origin. I will focus on general-nature management knowledge, i.e., knowledge dealing with how organizations should be governed to attain certain goals considered desirable - efficiency, profitability, etc. — and, more broadly, with the understanding of organizational phenomena. Thus, I left aside those specialized subdisciplines that some authors usually associate with administrative knowledge as constituent parts (e.g., marketing, finance, accounting). I begin my analysis by drawing a distinction between two ideal types of administrative knowledge, academic and popular, which constitute two cultural products that have different, yet somehow overlapping, institutional scopes of creation. Given this differentiation, I seek to answer three fundamental questions: (1) how does the local production of academic knowledge in the countries under analysis compare to that of developed countries? (2) Are there differences in the level of academic knowledge between both countries? (3) If so, how can we account for these differences?

The article is organized as follows. In the next section, I make some theoretical reflections on types of administrative knowledge and their relation with economic development. Then, I present the results of a bibliometric study of Argentine and Brazilian scholarly journals and explain the variations observed through an analysis of the institutionalization of the academic communities of both countries vis-à-vis the most salient features of their economies and higher education policies. Finally, I summarize the main conclusions of the study. 


\section{MANAGEMENT KNOWLEDGE AND ECONOMIC DEVELOPMENT}

Management knowledge is certainly heterogeneous and its concrete manifestations range from the routine administrative practices in organizations to the specialized academic literature. In this paper, I will focus on management knowledge as a product codified in publications of non-confidential access. Within this corpus of written production, two ideal types can be identified. The first is academic knowledge, constituted by the specialized literature that includes scholarly books, refereed journals and working papers of diverse sorts. The second is professional or popular knowledge, sometimes created by the same scholars who contribute to the former but targeted at an audience of professional or aspiring managers. It includes periodicals for managers and business magazines (e.g., Harvard Business Review, Sloan Management Review, Fortune) and specifically constitutes an extremely lucrative mass publishing market (Micklethwait \& Wooldridge, 1997). As both types aim at different audiences, they vary in style, language, expositive formalities, and criteria of argument validation.

This dichotomous classification has its own historicity. When management emerged as a study discipline, the first periodicals dealing with the subject (e.g., Transactions of the American Society of Mechanical Engineering) belonged to the strictly professional realm. The discipline's pioneers, such as Taylor and Fayol, combined professional activity with theoretical reflection and were mainly concerned with the search of practical solutions for organizational problems. The differentiation between both types of knowledge begins after World War II with the appearance of specialized journals (e.g., Administrative Science Quarterly) and the professionalization of the role of management professor, which required from scholars full-time dedication and greater commitment to the generation of academic knowledge of quality akin to that of other social sciences (Whitley, 1988). Thus, the way of generating management knowledge, which until then relied on individuals who simultaneously performed professional and academic roles, changed. This process of professionalization made increasingly difficult the dual exercise of these two roles in core countries (Engwall, Furusten, \& Wallerstedt, 2002), as it presented new demands motivated by different avenues of validation of professional performance: one subject to the scholarly logic of peer evaluation and guided by the standards of scientific activity and the other ruled by prestige-building through the selling of a particular know-how.

At present, there is a remarkable disconnection between both types of management knowledge. The fact that academic knowledge is no longer of interest for management practitioners is currently a matter of debate and concern (Bennis \& O'Toole, 2005; Brief, 2000; Hoffman, 2004; Pfeffer \& Fong, 2002). Academic management knowledge has a limited scope of production and diffusion, which is restricted to the scholarly community and constitutes the arena in which careers are validated and reputations are built under the logic of the much maligned 'publish or perish' imperative (Rond \& Miller, 2005).

For the purposes of this paper, the relevant question is how the creation of these types of knowledge relates to the level of economic development. Regarding academic management knowledge, and despite the paucity of studies addressing this issue, there is some evidence to sustain that LDCs are minor players (Baruch, 2001). Furthermore, several researchers' observations lend some support to the belief that local academic production in LDCs is low. For example, Üsdiken and Çetin (2001) emphasize the difficulties of penetration of the latest American scholarly theoretical developments into Turkish academia, whereas Alvarez et al. (1997) posit that Latin American business schools do not dedicate resources to research, which is indicative of low interest in the creation of academic knowledge. Nevertheless, and regarding popular management knowledge, it can be affirmed that although LDCs do not occupy a preponderant place in terms of original production, they certainly constitute a propitious field for its diffusion and consumption (Nogueira, 1990; Paes de Paula \& Wood, 2003). On the other hand, the very distinction between popular and academic management knowledge becomes diffuse as some countries' universities and business schools tend to present popular knowledge as a product of academic quality, thus suggesting that popular management is the form par excellence of administrative knowledge in LDCs (Gantman \& Parker, 2006). 
The role that the generation of scholarly management knowledge occupies in a country seems closely related to the institutionalization of an academic community that produces it and whose prestige depends on it, something that does not occur with popular management knowledge. In turn, the degree of institutionalization of this community is a function of a country's economic development. This follows from the fact that the production of scientific knowledge is governed by a sort of core-periphery division. The available evidence shows that most of this knowledge is generated within developed countries and that scientific communities in less developed or peripheral countries have a smaller size and lower degree of institutionalization than those in developed or core countries (Schott, 1998; Shrum \& Shenhav, 1995).

Although LDCs constitute an extremely heterogeneous set whose scientific production varies greatly according to the country and scientific discipline in question, it is reasonable to hypothesize regarding the consolidation of the management scholarly community that, within these countries, the richer ones count on a larger higher education system with more financial resources to sustain full-time professors. In spite of this, the degree of institutionalization of management and the development of a scholarly community in the discipline can be influenced by other factors. Thus, a country's level of economic development, as measured by Gross Domestic Product [GDP] per capita, could be less important than the size of the economy, which might stimulate the market's demand for the services produced by the business higher education industry. The importance of these economic factors (development and size) has been demonstrated in several studies by sociologists of science (Cole \& Phelan, 1999; Price, 1986; Schofer, 2004). Although it can be contended that scholarly output in the social sciences is less influenced by economic factors than that of the hard sciences, since the former are not subject to high infrastructure costs (e.g., laboratory equipment and supplies), there is also scientometric evidence that economic factors are positively correlated to the countries' productivity in the social sciences (Kishida \& Matsui, 1997), including the field of management (Gantman, 2009).

Moreover, a factor whose importance is critical in the development of science and technology in peripheral countries, and therefore in that of academic management knowledge, is the state's involvement in supporting higher education and promoting scientific research. For example, India, with its high level of scientific production relative to other less developed countries, is considered a successful case, accounted for by the active intervention of the state. Of course, other cultural, linguistic (i.e., English as the official language) and political aspects can also affect the consolidation of a management scholarly community, but for the purpose of this particular study three factors seem most relevant in accounting for differences in the production of management knowledge: (1) the level of economic development, (2) the size of the economy, and (3) the state's degree of support for the higher education system, particularly promoting scientific research by fostering full-time dedication by university professors. In the following section, I explore these ideas through an analysis of the level of scholarliness of domestic academic production in journals of Argentina and Brazil, two countries that have some characteristics in common (same regional location, extensive periods of political instability, similar institutions during their colonial period, language other than English, etc.).

\section{SCHOlARLy MANAGEMENT KNOWLEDGE IN ARGENTINA AND BRAZIL (1970-2002)}

\section{Data and Methods}

Specialized journals are perhaps the locus par excellence for the diffusion of scientific research, and many scientometric analyses view them as the main primary source. Therefore, I gathered data from Argentine and Brazilian scholarly periodicals in order to evaluate these countries' level of scholarliness in terms of academic production in the discipline. To this end, I used one basic indicator: the number of references by article. A brief digression is necessary to justify the election of this indicator. 
Science is a cultural artifact (Rouse, 1992; Woolgar, 1994) and, as such, its products are subject to a set of norms and conventions that vary greatly according to the historical and geographic contexts of reference. A basic convention of scholarly publications that has subsisted throughout the years is the recognition of the works and discoveries of others through citations and bibliographical references (Leydesdorff, 1998). Hence, and following other authors (e.g., Price, 1970; Üsdiken, 1996), I have taken the number of citations by article (usually denominated citation density) as an indicator of the level of scholarliness. Although perhaps imperfect, this is the only uniform and consistent indicator I have to estimate the scholarliness level of the production elaborated by these scientific communities. Another approach could be to evaluate the sophistication of the statistical approaches used in the papers, but few articles have made use of this type of quantitative analysis in the Argentine and Brazilian journals considered. I could also have extended the coverage to include publications of Argentine and Brazilian scholars in international refereed journals, but the number of publications by authors from these countries in such journals is too $\operatorname{low}^{(1)}$. Moreover, sociologists of science have already pointed out that the coverage of journals indexed in international databases is biased against LDCs (Gibb, 1995). Therefore, the most convenient way to really understand what type of scientific activity is carried out by LDCs researchers is the study of local publications.

The use of the number of citations may raise some objections. First, there appears to be among scientists in core countries a conventional normative criteria that 'the more citations the better'; but with science being a cultural product, why should this criterion be used to evaluate the scholarliness level of the scientific production in LDCs, as this standard may be alien to them? In this regard, I must clarify that my operationalization criterion does not imply making a judgment of value on the 'quality' of academic production of LDCs: I am not forming an opinion about its intrinsic value or merit, but measuring it in terms of a standard that the very scholarly community of these countries presumably knows and adopts. Scientific knowledge in the social sciences - and management is no exception - seems to flow from developed to less developed countries in which Alatas (2003) denominates 'academic dependency'. Some authors, like the Argentine sociologist Torcuato Di Tella (1974), attribute this virtually unidirectional flow to a sort of 'blinding effect' exerted by European and North American culture on the intellectuals of LDCs. In a similar vein, and already within the field of management, Caldas and Alcadipani (2005) suggest that Brazil has an 'inferiority complex', which might lead to a ritualistic consumption of administrative theories and techniques that originate in core countries (Wood \& Caldas, 2002). In any case, and regardless of the reason for this academic dependency, what is important here is that the standards of what constitutes 'good science' in core countries are accepted, perceived as desirable and, therefore, the object of emulation in peripheral countries, which justifies the choice of my indicator.

Second, another criticism of the use of citation density is that the belief in the desirability of citing many references in academic works has generated a tendency to cite unnecessarily. Diverse reasons may contribute to this 'citation inflation': (1) intentions to give a better impression of scholarliness, 2) motives of deference or friendship, etc. (Erkut, 2002). This could be a problem if the behavioral patterns inducing this phenomenon were idiosyncratic to academics of core countries only and not to their peers in LDCs, but there is no evidence supporting this assumption.

My analysis is based on the total of management articles published in the years 1970, 1974, 1978, 1982, 1986, 1990, 1994, 1998 and 2002 in the main management scholarly journal of each country, which I take as a representative sample of the total scholarly production from 1970 to 2005 . I chose 1970 as the starting year because that was when the Revista Administración de Empresas (Business Administration Review) was first published in Argentina; it was the most important journal in the discipline and virtually the only one for many years. It was aimed at management students, scholars and managers, so I consider it as an example of academic publication. As it was discontinued in 1989 and, given the inexistence of a similar academic publication, I took the journal La Información: Contabilidad y Administración (Information: Accounting and Administration) to evaluate the Argentine production in 1990. This review was basically targeted at accountants; hence it published very few management articles. In 1991, Alta Gerencia (Top Management) was launched, an Argentine journal similar to Revista Administración de Empresas in terms of academic level and predominance 
of management articles, so it is used as a data source for the years 1994 and 1998. As it was discontinued in 2001, I took for the year 2002 the contributions published in Enfoques: Contabilidad $y$ Administración (Approaches: Accounting and Management), a journal mainly dedicated to the first of these disciplines. Brazilian management journals have greater continuity than the Argentine ones, which itself constitutes a first indicator of the discipline's greater institutionalization. For all the years, I surveyed the articles published in Revista de Administração de Empresas (Business Administration Review), which began publication in 1961 and is considered by some as the discipline's main academic journal (Bertero \& Keinert, 1994).

I only surveyed articles on general management, sociology of organizations, industrial relations and human resources. Therefore, I did not consider all the articles published in the journals in question, whose coverage is quite eclectic as it includes topics of accounting, finance, marketing, computer science, production management, public administration, economics and even political science. The contributions to sections of interviews, book reviews and annotated bibliographies, as well as the shorter articles published in RAE-Light, a supplement of the Brazilian Revista de Administração de Empresas basically targeted at professional managers, were not considered either. In addition, articles translated from foreign journals and those written by authors affiliated with institutions of other countries (e.g., three articles by Argentine authors published in RAE-Brazil) were also excluded.

In order to make a comparison with the citation density of international scholarly journals, I took the articles of a leading journal in the field, Administrative Science Quarterly, for all years under analysis.

To arrive at a representative indicator of the level of scholarliness of the journals selected in each year, I computed the average citation density of all articles. In addition, I checked for the presence of outliers that could disproportionately affect this average using Dixon's test (Barnett \& Lewis, 1994) and excluded those articles that could be considered outliers with a significance level of $p<0.01$.

Finally, for the narrative account of the main differences between the scholarly communities of Argentina and Brazil, as well as the analysis of the differences in public policies and economic performance in both countries, I relied on selected secondary sources as reported below.

\section{Results and Discussion}

The results of the bibliometric analysis are reported in Table 1. The first column indicates the reference year. The second, split into subcolumns for each country, shows the total number of management articles of the journals selected; and the third, the number of contributions by local authors. The fourth contains the yearly average citation density. Finally, for comparison purposes, the fifth column presents the citation density of the international journal. 
Table 1

Bibliometric Analysis of Selected Argentine and Brazilian Management Journals (1970-2002)

\begin{tabular}{|c|c|c|c|c|c|c|c|}
\hline \multirow[t]{2}{*}{ Year } & \multicolumn{2}{|c|}{$\begin{array}{l}\text { Total management } \\
\text { articles }\end{array}$} & \multicolumn{2}{|c|}{$\begin{array}{c}\text { Total management articles by } \\
\text { local authors }\end{array}$} & \multicolumn{2}{|c|}{ Yearly average citation density } & \multirow[t]{2}{*}{$\begin{array}{l}\text { Yearly average citation density } \\
\text { of international journal }(*)\end{array}$} \\
\hline & Argentina (x) & Brazil (+) & Argentina (x) & Brazil (+) & Argentina (x) & Brazil (+) & \\
\hline 1970 & 12 & 10 & 3 & 8 & 0 & 12.38 & 25.48 \\
\hline 1974 & 26 & 9 & 3 & 7 & 3.33 & 10.86 & 32.83 \\
\hline 1982 & 37 & 15 & 9 & 14 & 9.56 & 13.86 & 54.06 \\
\hline 1986 & 22 & 21 & 9 & 20 & 5.33 & 16.60 & 47.22 \\
\hline 1990 & 2 & 17 & 2 & 14 & 0 & 17.57 & 59.65 \\
\hline 1994 & 42 & 38 & 33 & 34 & $4.97(1)$ & 18.41 & 61.77 \\
\hline 1998 & 19 & 11 & 19 & 9 & 8.74 & 18.67 & 87 \\
\hline 2002 & 21 & 27 & 21 & 10 & $5.25(2)$ & 25.80 & 76.38 \\
\hline
\end{tabular}

Notes. (1) $n=32$, one outlier excluded. (2) $n=20$, one outlier excluded.

Sources: (x) Revista de Administración de Empresas (1970, 1974, 1978, 1982, 1986), La Información: Contabilidad y Administración (1990), Alta Gerencia (1994, 1998), Enfoques: Contabilidad y Administración (2002). (+) Revista de Administração de Empresas (1970, 1974, 1978, 1982, 1986, 1990, 1994, 1998, 2002). (*) Administrative Science Quarterly (1970, 1974, 1978, 1982, 1986, 1990, 1994, 1998, 2002). 
A few caveats are in order in relation to the data on this table. The large difference in the yearly number of articles published in Argentine journals is due to the use of different journals as sources and to the fact that some journals' publication frequency differs. For example, I utilized for 1990 the Argentine journal La Información: Contabilidad y Administración, a quarterly publication that mainly published accounting articles, hence the low number of management articles for this year. Alta Gerencia, the journal considered for 1994 and 1998, reduced its publication frequency in this latter year, which explains the decrease in the number of articles from 38 to 11. The high number of articles for 2002 in Argentina is due to the fact that the source, Enfoques: Contabilidad y Administración, is a monthly periodical. Changes in publication frequency also affected the number of articles of the Brazilian Revista de Administração de Empresas. In addition, there is a reduction of the number of local management articles published in this journal and a concomitant increase in that of articles by foreign authors in 2002. This should not be interpreted as a decrease in productivity on the part of Brazilian scholars, since in the 1990s other management journals began publication in this country (e.g., Revista de Administração Contemporânea in 1997). Actually, as a sort of additional control and following the same methods specified above, I computed the yearly average citation density for Revista de Administração Contemporânea. The resulting figures were similar, although slightly higher, than those of Revista de Administração de Empresas: 19.55 for $1998(\mathrm{n}=20)$ and $26.82(\mathrm{n}$ $=28$ ) for 2002. I also computed this indicator for the Revista de Administração da Universidade de São Paulo [RAUSP], which has been uninterruptedly published since 1977. In 1978, its average number of references, considering 11 management articles was 12.18. For 1982, this indicator was $11.53(\mathrm{n}=$ 17); for 1986, $10.19(\mathrm{n}=31)$; for 1990, $11.38(\mathrm{n}=29)$; for 1994, $19.46(\mathrm{n}=26)$; for $1998,20.70(\mathrm{n}=$ 20); and for 2002, $23.70(n=17)$. Again, the results were very similar to those of the RAE.

The most relevant finding that can be drawn from these data is that the articles published in academic Brazilian journals have a higher level of scholarliness than those of Argentine ones, as indicated by the average citation densities. I also used the Mann-Whitney $U$ test for unpaired samples to see if the difference of the medians of citation density was statistically significant. According to this test, the difference between the level of scholarliness of both countries' journals was statistically significant in most years ( $<<0.05$ for 1970, 1986, 1990, 1998; $p<0.01$ for 2002; and $p<0.001$ for 1994). Yet despite being somehow higher than the Argentine one, the level of scholarliness of Brazilian journals is lower than that of the international journal taken as benchmark. This conclusion is also statistically significant $(\mathrm{p}<0.001$ for all years, except 1970 with $\mathrm{p}<0.05)$. For a developing country, the institutionalization of management as an academic discipline is high in Brazil; yet as Roesch (2003), a Brazilian scholar affiliatiated with the London School of Economics, argues, there is still much left to do in Brazil to reach the scholarly level of core countries. In the Argentine case, the bibliometric analysis suggests that its academics generate a knowledge that seems more oriented to the practitioner realm, given the low number of citations. In order to explain the difference in development of academic knowledge in these two countries, what must be examined is the degree of consolidation of an independent academic community.

In Argentina, the lack of institutionalization of the academic profession, understood as a full-time occupation and main source of income for its members, is something that many local authors (e.g., Follari, 2003; Stubrin, 2003) identify in their policy papers as one of the main defects of the country's higher education system The problems that this entails has clearly been noticed, among others, by Wainerman (1999, p. 4), a recognized Argentine sociologist who describes the realm of postgraduate education in the social sciences as covered by a 'ghostly halo' surrounding institutions, students, and teachers, emphasizing that the absolute majority of these latter do not have full-time dedication. Nevertheless, this is not perceived as a problem within management higher education in which professors earn most of their income by working as managers or consultants. Although some private institutions have greatly expanded their full-time management faculty in the last decade (in particular, Universidad de San Andrés and Instituto de Altos Estudios [IAE], being a full-time professor in the discipline is still rare in Argentina, especially at public universities.

In fact, it is a widely held belief in the realm of management education that, in order to teach this discipline, it is not only necessary to have a university degree, but also, and most importantly, an 

(1970-2005)

outstanding professional career. In this regard, what Seró (2001, p. 5) writes in her case study about the Masters Program in Public Administration of the Universidad de Buenos Aires, one of the most prestigious programs of the country, is illustrative:

Our professors do not have full-time dedication .... This situation ....reduces their availability in terms of time. But it adds an irreplaceable value to them .... They live the problems, rather than only read about them and compare them with theoretical models; they must make decisions, not only analyze them; they conceive and implement policies, they do not just "imagine" them. Knowledge is not enough for them. They must know how to do, know how to act, know how to be.

This positive appreciation is a feature not only of higher education in management but also in other professional disciplines like Law and Engineering. As in the case of other Latin American countries (Levy, 1986), this allows us to characterize Argentine higher education as professionalist.

Despite being a Latin American country, Brazil escapes this tendency, at least partially. In this country, the institutionalization of the university profession is a main feature of the higher education system (Schwartzman \& Balbachevsky, 1997). The Brazilian university system is of more recent creation than that of other Latin American countries. While universities like the Universidad National de Córdoba in Argentina date from the seventeenth century, the first Brazilian university was founded in the 1930s. Perhaps the relative youth of the system facilitated a radical change, an authentic refounding, with the university reform of 1968 , which aimed to create a higher education system patterned after the American model (Schwartzman, 1991, 1992). The pillar of this system is postgraduate education, and teaching is understood as being intrinsically linked to research, a conception that demands the creation of the academic profession.

In sum, the institutionalization of the full-time university career was the result of a process of coercive isomorphism (DiMaggio \& Powell, 1983), by which the regulatory power of the State imposed the replication of the American model. Business education is framed within the same logic of the higher education system of which it is part. Whereas in Argentina the first MBA offered by a university dates from the 1980s, Brazilian postgraduate degrees in businesses administration were first offered in the 1960s (Curado, 1994). This enabled Brazil, in which the ANPAD (the Associação Nacional de Pós-Graduação e Pesquisa em Administração that functions as a Brazilian Academy of Management) was founded in 1978, to count on a critical mass of postgraduates in the discipline (Cunha et al., 1997). Of course, the fact that many postgraduate programs exist does not necessarily mean that the academic management community has been fully institutionalized. According to Wood and Paes de Paula (2003, p. 15), being a full-time management professor 'is relatively uncommon in Brazil', which marks an important difference with many core countries and perhaps explains the lower level of scholarliness of Brazilian authors relative to that of international journals. However, the professionalization of management academia in Brazil is greater today than in the 1960s, which owes much to the action of the CAPES, Coordenação de Aperfeiçoamento de Pessoal de Superior Nível, a Brazilian state agency dedicated to strengthening postgraduate education (Bertero, 2006). By virtue of it, there was a significant increase in the amount of academic production (Bertero, 2006; Tonelli, Caldas, Braga Lacombe, \& Tinoco, 2003), which indicates that the 'publish or perish' began to be taken into account by management professors in Brazil for advancement in their careers, especially those working at public universities, some of whom do have full time dedication. As an illustration of Brazilian scholarly production, it may be worth mentioning that at the 2002 annual meeting of ANPAD two thousand papers were presented, an impressive figure as it is almost half the number of submissions to the 2002 Academy of Management Meeting in the United States (Quintella, 2003) ${ }^{(2)}$.

Although few data about the full-time dedication of management professors in these countries are available, there is some information about their two largest and more prestigious universities: Universidad de Buenos Aires [UBA] in Argentina and Universidade de São Paulo [USP] in Brazil. The Census of the UBA (2005) indicates that its Facultad de Ciencias Económicas (School of Economic Sciences) had 2208 professors, of which only 52 had full-time dedication in the year 2004. In contrast, its counterparts at the USP (2007), Faculdades de Economia, Administração $e$ 
Contabilidade (campus São Paulo and Ribeirão Preto), had 236 professors in the same year, of which 152 had full-time dedication.

In sum, differences in the development of the academic communities of Argentina and Brazil exist, and consequently it is necessary to analyze why this is so. The wealth of each country, as measured by GDP per capita, could be one of them; but this factor does not seem to have explanatory power, since the GDP per capita of Argentina is higher than that of Brazil. In 1970, Argentina had a GDP per capita of 1295 constant dollars of 2004, whereas that of Brazil amounted to only 699 dollars (United Nations [UN], 2006). This difference has tended to reduce: in 2004, Argentine GDP was 3987 constant dollars of this year and the Brazilian one was 3224 dollars. The bridging of this gap in GDP per capita responds basically to the superior performance of the Brazilian economy relative to that of Argentina. This leads us to another relevant variable for explaining the degree of institutionalization of the academic community: the size of the economy.

In 1970, the Brazilian economy was larger than that of Argentina, but not too much: Argentine GDP was 122,811 million constant dollars of 2004, whereas Brazilian GDP surpassed it by $36 \%$, with 166,902 million (UN, 2006). Back then, there were evident problems of growth in the Argentine economy, while Brazil's proved to be more dynamic. During the following years, Brazil exhibited a growth trajectory different than that of Argentina. By 2003, Brazil had clearly stretched its lead over Argentina in terms of size of the economy: Brazilian GDP amounted to 588,287 million constant dollars of 2004, almost tripling that of Argentina with 198,162 million dollars. The reasons for which the economic growth paths of both countries differ lie outside the scope of this study and continue to puzzle economists and sociologists, but it is clear that in the last forty years Brazil has managed to consolidate its position as the largest Latin American economy (Bértola \& Porcile, 2006). With greater social inequality than Argentina, Brazil is a dual society, which some Brazilian economists (Bacha, 1974) describe as Belindia: a mix of a small country with a huge and poor one. But the larger size of the Brazilian economy, as well as its higher level of industrial development vis-à-vis Argentina, implies greater demand for business administration professionals, which represents an opportunity for the business higher education industry. Yet while this factor can positively contribute to the emergence and support of the academic community, it might not be a sufficient condition to explain it. In order to understand the level of development of the academic community in Brazil, a third factor must be analyzed: the active role of the state.

The implementation of the Brazilian university system could not have occurred without the involvement of different levels of government with the national system of science and technology, which succeeded in placing Brazil in an outstanding position among LDCs in terms of scientific production (Schwartzman \& Balbachevsky, 1997). By funding full-time teaching positions at universities, the Brazilian state clearly demonstrated a political commitment with the development of higher education. Management education did not escape this trend and was also a governmental priority, much more than in Argentina. The Getulio Vargas Foundation, named after an ex-president and strong man of Brazil, was founded in 1944 to advance administrative knowledge in public and private organizations. Soon, this institution placed itself at the cutting edge of management education in the country (Martins, 1989), establishing its first postgraduate management program in 1959 (Curado, 1994). No similar institution was created in Argentina.

It must also be pointed out that full-time dedication of professors is so important in Brazilian universities that the legal definition of a university itself contemplates this aspect. In fact, Article 52 of Brazilian law 9.394/96 states as a requirement that one third of the number of professors must have full-time dedication. There is no similar provision in Argentine legislation, and the proportion of full time professors (including teaching assistants) to their total number was 11.47 for the year 2006 in Argentine public universities, according to data from the Ministerio de Educación (2007). Moreover, the Brazilian state devotes more funds as a percentage of GDP than its Argentine counterpart in science and technology activities, most of which are carried out by public universities: $1.65 \%$ and $1.12 \%$ against $0.33 \%$ and 0.53 of Argentina for the years 1990 and 2005, respectively (Red Iberoamericana de Ciencia y Tecnología [RICyT], 2008). 
However, perhaps the state's deep commitment to higher education might not be enough to account for the greater development of the academic community in Brazil. Moreover, it is important to note that the Brazilian higher education system was almost created from zero and, therefore, there was no resistance to change on the part of an academic elite. Argentine universities, with an academic elite used to capitalizing on the professional realm its scholarly prestige, did not constitute a propitious field for faculty professionalization (i.e., full-time dedication to research and teaching). This is an element of institutional inertia (Hannan \& Freeman, 1989) that even today would be difficult to overcome.

This leads us to reflect once again on the two ideal types of management knowledge: the popular and the academic. Where an academic community independent of the professional one does not exist, there is no disconnection between both types of knowledge, and publications whose articles would be considered as nonacademic in the context of a developed country enjoy academic prestige. A greater degree of independence, as would seem to be the case in Brazil, seems to be associated with greater differentiation in the production of both types of knowledge and with the recognition of the disconnection between them, as demonstrated by the works of some Brazilian authors (Bertero, Caldas, \& Wood, 1999; Mattos, 2003).

\section{CONCLUSION}

This study aimed to advance our comprehension of the processes of creation and diffusion of management knowledge in developing countries by focusing on the characteristics of the domestic production of academic knowledge. It has been demonstrated that scholarly production in two countries of relatively high economic development within the universe of LDCs has a lower level of scholarliness than that of developed countries. This can be explained by the insufficient degree of institutionalization of an academic community with its own criteria of validation and reproduction. Such a finding is to some extent compatible with the opinion of Alvarez et al. (1997, p. 577), who suggested that Latin America suffered from a "lack of academic capabilities in the field".

However, what the present study reveals is that this apparent lack of academic capabilities is not homogeneous across the region. Of the two countries studied, the Brazilian academic community shows a greater degree of institutionalization; consequently, this country exhibits a greater level of production of local academic knowledge. Argentina, in contrast, does not have an independent management academic community, but one that is closely linked to, and almost indistinguishable from, the professional community. Consistently with this, the level of its scholarly production comes closer to popular knowledge than to the academic one, at least in terms of the standards of international scientific publications.

The difference between the countries under study can be largely accounted for by the size of their economies and the state's degree of involvement in the strengthening of higher education, specifically in promoting faculty professionalization as well as in trying to adopt the American higher education model. This latter aspect is an example of coercive isomorphism in the Brazilian university system. As we have seen, this strategy did not completely succeed in separating the academic community from the professional community in Brazil, yet it offers a clear contrast with the Argentine case in which, in the absence of pressure to work full-time at public universities, professors live comfortably in both worlds: the academic and the professional.

The research presented here suggests some avenues for further research. In particular, there is a need for a deeper comparative historical analysis of the processes by which academic elites were constituted in both countries, with a special focus on the role played by the State in this regard. In addition, and also in relation to this issue, it is important to find out whether the existing differences in the development of scholarly management in Argentina and Brazil are also evident in cognate scientific fields such as economics, as well as in the social sciences in general. Moreover, the analysis of this paper does not necessarily exhaust the consideration of the mechanisms that explain the differences in 
academic management knowledge in both countries. In fact, the same explanatory factor(s) behind the success of the Brazilian model of development relative to the Argentine one could also be relevant in accounting for the greater institutionalization of scholarly management knowledge in Brazil. In short, and although further comparative research is needed to assess whether the conclusions obtained can be generalized to other less developed countries, this study has clearly shown that the state's higher education policies play a determinant role in the institutionalization of scholarly management research.

\section{ACKNOWLEDGMENTS}

The author wishes to thank Rafael Alcadipani, Eduardo Scarano, and two anonymous reviewers for their helpful comments on this paper.

\section{NOTES}

\footnotetext{
${ }^{1}$ In his study about international participation in management research using a dataset of all articles published in seven leading journals of the discipline (Academy of Management Review, Academy of Management Journal, Administrative Science Quarterly, Group and Organization Management, Human Relations, Journal of Organizational Behavior, and Organization Studies) in the years 1980, 1985, 1990, and 1995, Baruch (2001) stated that the only Third World country represented was Brazil with just one co-authorship. I analyzed all contributions in the same journals, excluding editorials and book reviews, for the years $2000(\mathrm{n}=707)$ and $2005(\mathrm{n}=761)$ and found that there were no authorships by scholars affiliated to Argentine or Brazilian institutions.

${ }^{2}$ Again, it is interesting to compare this with the Argentine case. In Argentina, the number of papers presented to academic meetings during the period 1974 to 2002 was 373. The year with the highest number of paper presentations was 1998 when two different meetings were held and fifty contributions were presented. In 2002, there were also two meetings, and only 33 papers were presented Gilli, J. J., \& Sastre, R. (2004). El saber administrativo visto desde la perspectiva de los congresos organizados por el Consejo Profesional de Ciencias Económicas. In F. Suárez, S. Agoff, M. Contreras, M. Losano, \& M. Zonis. Construcción del saber administrativo en la Argentina: una aproximación operacional. Buenos Aires: Facultad de Ciencias Económicas de la Universidad de Buenos Aires. To further illustrate the dimension of Brazilian management studies, it must be indicated that in only a single theoretical approach within organization studies, the neoinstitutional theory, there were 299 Brazilian contributions to local conferences and journals in the 1993-2007 period Guarido, E. R., Filho. (2008). A construção da teoria institucional nos estudos organizacionais no Brasil: o período 1993-2007. Tese de doutorado, Universidade Federal do Paraná, Curitiba, PR, Brazil.
}

\section{REFERENCES}

Administrative Science Quarterly. (1970). 15(1).

Administrative Science Quarterly. (1970). 15(2).

Administrative Science Quarterly. (1970). 15(3).

Administrative Science Quarterly. (1970). 15(4).

Administrative Science Quarterly. (1974). 19(1).

Administrative Science Quarterly. (1974). 19(2).

Administrative Science Quarterly. (1974). 19(3).

Administrative Science Quarterly. (1974). 19(4). 

(1970-2005)

Administrative Science Quarterly. (1978). 23(1).

Administrative Science Quarterly. (1978). 23(2).

Administrative Science Quarterly. (1978). 23(3).

Administrative Science Quarterly. (1978). 23(4).

Administrative Science Quarterly. (1982). 27(1).

Administrative Science Quarterly. (1982). 27(2).

Administrative Science Quarterly. (1982). 27(3).

Administrative Science Quarterly. (1982). 27(4).

Administrative Science Quarterly. (1986). 31(1).

Administrative Science Quarterly. (1986). 31(2).

Administrative Science Quarterly. (1986). 31(3).

Administrative Science Quarterly. (1986). 31(4).

Administrative Science Quarterly. (1990). 35(1).

Administrative Science Quarterly. (1990). 35(2).

Administrative Science Quarterly. (1990). 35(3).

Administrative Science Quarterly. (1990). 35(4).

Administrative Science Quarterly. (1994). 39(1).

Administrative Science Quarterly. (1994). 39(2).

Administrative Science Quarterly. (1994). 39(3).

Administrative Science Quarterly. (1994). 39(4).

Administrative Science Quarterly. (1998). 43(1).

Administrative Science Quarterly. (1998). 43(2).

Administrative Science Quarterly. (1998). 43(3).

Administrative Science Quarterly. (1998). 43(4).

Administrative Science Quarterly. (2002). 47(1).

Administrative Science Quarterly. (2002). 47(2).

Administrative Science Quarterly. (2002). 47(3).

Administrative Science Quarterly. (2002). 47(4).

Alatas, S. (2003). Academic dependency and the global division of labour in the social sciences. Current Sociology, 51(6), 599-613.

Alta Gerencia. (1994). 4(28). 
Alta Gerencia. (1994). 4(29).

Alta Gerencia. (1994). 4(30).

Alta Gerencia. (1994). 4(31).

Alta Gerencia. (1994). 4(32).

Alta Gerencia. (1994). 4(33).

Alta Gerencia. (1994). 4(34).

Alta Gerencia. (1994). 4(35).

Alta Gerencia. (1994). 4(36).

Alta Gerencia. (1994). 4(37).

Alta Gerencia. (1994). 4(38).

Alta Gerencia. (1994). 4(39).

Alta Gerencia. (1998). 8(55).

Alta Gerencia. (1998). 8(56).

Alta Gerencia. (1998). 8(57).

Alta Gerencia. (1998). 8(58).

Alvarez, J. L. (Ed.). (1998). The diffusion and consumption of business knowledge. New York: St. Martin's Press.

Alvarez, J. L., Enrione, A., \& Mazza, C. (1997). Legitimation and integration through dependency: graduate business education in Latin America. Organization, 4(4), 564-581.

Augier, M. E., March, J. G., \& Sullivan, B. Ni. (2005). Notes on the evolution of a research community: organization studies in anglophone North America, 1945-2000. Organization Science, 16(1), 85-95.

Bacha, E. (1974). El economista y el Rey de Belindia: una fábula para tecnócratas. Cuadernos de Economía, 11(33), 60-64.

Barnett, V., \& Lewis, T. (1994). Outliers in statistical data. Chichester: John Wiley.

Baruch, Y. (2001). Global or North American? A geographical based comparative analysis of publications in top management journals. International Journal of Cross Cultural Management 1(1), 109-126.

Bennis, W., \& O'Toole, J. (2005). How business schools lost their way. Harvard Business Review, 83(5), 96-104.

Bertero, C. O. (2006). A RAE nos seus 45 Anos. Revista de Administração de Empresas, 46(2), 114-117.

Bertero, C. O., \& Keinert, T. M. M. (1994). A evolução da análise organizacional no Brasil (1961-93). Revista de Administração de Empresas, 34(3), 81-90.

Bertero, C. O., Caldas, M., \& Wood, T. (1999). Produção científica em administração de empresas: provocações, insinuações e contribuições para um debate local. Revista de Administração Contemporânea, 3(1), 147-178. 
Bértola L. \& Porcile, G. (2006). Convergence, trade and industrial policy: Argentina, Brazil and Uruguay in the international economy, 1900-1980. Revista de Historia Económica, 24(1), 37 68.

Brief, A. P. (2000). Still servants of power. Journal of Management Inquiry, 9(4), 342-351.

Caldas, M., \& Alcadipani, R. (2005, December). (North) Americanizing Latin America: a postcolonialist account of the Americanization of Brazilian Management. Proceedings of the Iberoamerican Academy of Management, Lisboa, Portugal.

Cole, S., \& Phelan, T. (1999). The scientific productivity of nations. Minerva, 37(1), 1-23.

Cunha, A. S. M. da, Corrêa, V. A., Vasconcellos, E., Fachin, R. C., Venosa, R., Machado-da-Silva, C. L., Rodrigues, S. B., Fischer, T., Spink, P., \& Moreno, R. (1997). A Associação Nacional dos Programas de Pós-Graduação em Administração nas palavras de seus presidentes. Revista de Administração Contemporânea, 1(1), 145-173.

Curado, I. B. (1994). EAESP-FGV: um passeio pelo labirinto. Revista de Administração de Empresas, 34(3), 8-24.

Di Tella, T. (1974). Clases sociales y estructuras políticas. Buenos Aires: Paidos.

DiMaggio, P., \& Powell, W. (1983). The iron cage revisited: institutional isomorphism and collective rationality in organizational fields. American Sociological Review, 48(2), 147-160.

Enfoques - Contabilidad y Administración. (2002). 3(1).

Enfoques - Contabilidad y Administración. (2002). 3(2).

Enfoques - Contabilidad y Administración. (2002). 3(3).

Enfoques - Contabilidad y Administración. (2002). 3(4).

Enfoques - Contabilidad y Administración. (2002). 3(5).

Enfoques - Contabilidad y Administración. (2002). 3(6).

Enfoques - Contabilidad y Administración. (2002). 3(7).

Enfoques - Contabilidad y Administración. (2002). 3(8).

Enfoques - Contabilidad y Administración. (2002). 3(9).

Enfoques - Contabilidad y Administración. (2002). 3(10).

Enfoques - Contabilidad y Administración. (2002). 3(11).

Enfoques - Contabilidad y Administración. (2002). 3(12).

Engwall, L. (2007). The anatomy of management education. Scandinavian Journal of Management, 23(1), 4-35.

Engwall, L., \& Kipping, M. (Eds.). (2003). Management consulting: emergence and dynamics of a knowledge industry. Oxford: Oxford University Press.

Engwall, L., Furusten, S., \& Wallerstedt, E. (2002). The changing relationship between management consulting and academia: evidence from Sweden. In L. Engwall \& M. Kipping (Eds.). Management consulting: emergence and dynamics of a knowledge industry (pp. 36-51). Oxford: Oxford University Press. 
Erkut, E. (2002). Measuring Canadian business school research output and impact. Canadian Journal of Administrative Sciences, 19(2), 97-123.

Follari, R. (2003). Aspectos teóricos y metodológicos sobre evaluación de la función investigación en las universidades [Serie Estudios $\mathrm{N}^{\circ} 2$ ]. Buenos Aires: CONEAU.

Gantman, E. (2009). International differences of productivity in scholarly management knowledge. Scientometrics, 80(1), 153-165.

Gantman, E., \& Parker, M. (2006). Comprador management? Organizing management knowledge in Argentina (1975-2003). Critical Perspectives on International Business, 2(1), 25-40.

Gibb, W. W. (1995). Lost science in the third world. Scientific American, 273(2), 92-99.

Hannan, M., \& Freeman, J. (1989). Organizational ecology. Cambridge, MA: Harvard University Press.

Hoffman, A. (2004). Reconsidering the role of the practical theorist: on (re)connecting theory to practice in organization theory. Strategic Organization, 2(2), 213-222.

Ibarra-Colado, E. (2006). Organization studies and epistemic coloniality in Latin America: thinking otherness from the margins. Organization, 13(4), 463-488.

Kishida, K., \& Matsui, S. (1997). International publication patterns in social sciences: a quantitative analysis of the IBSS file. Scientometrics, 40(2), 277-298.

La Información: Contabilidad y Administración. (1990). 6(1).

La Información: Contabilidad y Administración. (1990). 6(2).

La Información: Contabilidad y Administración. (1990). 6(3).

La Información: Contabilidad y Administración. (1990). 6(4).

Levy, D. (1986). Higher education and the state in Latin America. Chicago, IL: University of Chicago Press.

Leydesdorff, L. (1998). Theories of citation? Scientometrics, 43(1), 5-25.

Martins, C. (1989). Surgimento e expansão dos cursos de administração no Brasil (1952-1983). Ciência e Cultura, 41(7), 663-676.

Mattos, P. L. (2003). O que diria Popper à literatura administrativa de mercado? Revista de Administração de Empresas, 43(1), 60-69.

Micklethwait, J., \& Wooldridge, A. (1997). The witch doctors: making sense of the management gurus. New York: Times Business.

Ministerio de Educación. (2007). Anuario de estadísticas universitárias 2006. Buenos Aires: Ministerio de Educación, Ciencia y Tecnología de la República Argentina.

Nogueira, R. M. (1990). El perfeccionamiento de la gerencia argentina: las tareas pendientes. La Información: Contabilidad y Administración, 6(2), 121-132.

Paes de Paula, A. P., \& Wood, T. (2003, December). Viagem epistemológica às livrarias dos aeroportos. Proceedings of the International Conference, Iberoamerican Academy of Management, São Paulo, SP, Brazil, 3.

Pfeffer, J., \& Fong, C. (2002). The end of business schools? Less success than meets the eye. Academy of Management Learning and Education, 1(1), 78-96. 
Price, D. J. S. de (1970). Citation measures of hard science, soft science, technology, and nonscience. In C. Nelson \& D. Pollock (Eds.). Communication among scientists and engineers (pp. 3-22). Lexington, MA: Heath.

Price, D. J. S. de (1986). Little science, big science - and beyond. New York: Columbia University Press.

Quintella, R. H. (2003). Encontro nacional da ANPAD X Meeting of AOM: lições, questionamentos e especulações. Revista de Administração de Empresas, 43(1), 107-115.

Red Iberoamericana de Ciencia y Tecnología. (2008). Gasto en ciencia y tecnología en relación al PBI. Retrieved April 20, 2008, from http://www.ricyt.org/indicadores/comparativos/05.xls

Revista de Administração de Empresas. (1970). 10(1).

Revista de Administração de Empresas. (1970). 10(2).

Revista de Administração de Empresas. (1970). 10(3).

Revista de Administração de Empresas. (1970). 10(4).

Revista de Administração de Empresas. (1974). 14(1).

Revista de Administração de Empresas. (1974). 14(2).

Revista de Administração de Empresas. (1974). 14(3).

Revista de Administração de Empresas. (1974). 14(4).

Revista de Administração de Empresas. (1974). 14(5).

Revista de Administração de Empresas. (1974). 14(6).

Revista de Administração de Empresas. (1978). 18(1).

Revista de Administração de Empresas. (1978). 18(2).

Revista de Administração de Empresas. (1978). 18(3).

Revista de Administração de Empresas. (1978). 18(4).

Revista de Administração de Empresas. (1982). 22(1).

Revista de Administração de Empresas. (1982). 22(2).

Revista de Administração de Empresas. (1982). 22(3).

Revista de Administração de Empresas. (1982). 22(4).

Revista de Administração de Empresas. (1986). 26(1).

Revista de Administração de Empresas. (1986). 26(2).

Revista de Administração de Empresas. (1986). 26(3).

Revista de Administração de Empresas. (1986). 26(4).

Revista de Administração de Empresas. (1990). 30(1).

Revista de Administração de Empresas. (1990). 30(2).

Revista de Administração de Empresas. (1990). 30(3). 
Revista de Administração de Empresas. (1990). 30(4).

Revista de Administração de Empresas. (1994). 34(1).

Revista de Administração de Empresas. (1994). 34(2).

Revista de Administração de Empresas. (1994). 34(3).

Revista de Administração de Empresas. (1994). 34(4).

Revista de Administração de Empresas. (1994). 34(5).

Revista de Administração de Empresas. (1994). 34(6).

Revista de Administração de Empresas. (1998). 38(1).

Revista de Administração de Empresas. (1998). 38(2).

Revista de Administração de Empresas. (1998). 38(3).

Revista de Administração de Empresas. (1998). 38(4).

Revista de Administração de Empresas. (2002). 42(1).

Revista de Administração de Empresas. (2002). 42(2).

Revista de Administração de Empresas. (2002). 42(3).

Revista de Administração de Empresas. (2002). 42(4).

Revista de Administración de Empresas. (1970). 1(1).

Revista de Administración de Empresas. (1970). 1(2).

Revista de Administración de Empresas. (1970). 1(3).

Revista de Administración de Empresas. (1970). 1(4).

Revista de Administración de Empresas. (1970). 1(5).

Revista de Administración de Empresas. (1970). 1(6).

Revista de Administración de Empresas. (1970). 1(7).

Revista de Administración de Empresas. (1970). 1(8).

Revista de Administración de Empresas. (1970). 1(9).

Revista de Administración de Empresas. (1970). 1(10).

Revista de Administración de Empresas. (1970). 1(11).

Revista de Administración de Empresas. (1970). 1(12).

Revista de Administración de Empresas. (1974). 5(1).

Revista de Administración de Empresas. (1974). 5(2).

Revista de Administración de Empresas. (1974). 5(3).

Revista de Administración de Empresas. (1974). 5(4). 
Revista de Administración de Empresas. (1974). 5(5).

Revista de Administración de Empresas. (1974). 5(6).

Revista de Administración de Empresas. (1974). 5(7).

Revista de Administración de Empresas. (1974). 5(8).

Revista de Administración de Empresas. (1974). 5(9).

Revista de Administración de Empresas. (1974). 5(10).

Revista de Administración de Empresas. (1974). 5(11).

Revista de Administración de Empresas. (1974). 5(12).

Revista de Administración de Empresas. (1978). 9(1).

Revista de Administración de Empresas. (1978). 9(2).

Revista de Administración de Empresas. (1978). 9(3).

Revista de Administración de Empresas. (1978). 9(4).

Revista de Administración de Empresas. (1978). 9(5).

Revista de Administración de Empresas. (1978). 9(6).

Revista de Administración de Empresas. (1978). 9(7).

Revista de Administración de Empresas. (1978). 9(8).

Revista de Administración de Empresas. (1978). 9(9).

Revista de Administración de Empresas. (1978). 9(10).

Revista de Administración de Empresas. (1978). 9(11).

Revista de Administración de Empresas. (1978). 9(12).

Revista de Administración de Empresas. (1982). 13(1).

Revista de Administración de Empresas. (1982). 13(2).

Revista de Administración de Empresas. (1982). 13(3).

Revista de Administración de Empresas. (1982). 13(4).

Revista de Administración de Empresas. (1982). 13(5).

Revista de Administración de Empresas. (1982). 13(6).

Revista de Administración de Empresas. (1982). 13(7).

Revista de Administración de Empresas. (1982). 13(8).

Revista de Administración de Empresas. (1982). 13(9).

Revista de Administración de Empresas. (1982). 13(10).

Revista de Administración de Empresas. (1982). 13(11). 
Revista de Administración de Empresas. (1982). 13(12).

Revista de Administración de Empresas. (1986). 17(1).

Revista de Administración de Empresas. (1986). 17(2).

Revista de Administración de Empresas. (1986). 17(3).

Revista de Administración de Empresas. (1986). 17(4).

Revista de Administración de Empresas. (1986). 17(5).

Revista de Administración de Empresas. (1986). 17(6).

Revista de Administración de Empresas. (1986). 17(7).

Revista de Administración de Empresas. (1986). 17(8).

Revista de Administración de Empresas. (1986). 17(9).

Revista de Administración de Empresas. (1986). 17(10).

Revista de Administración de Empresas. (1986). 17(11).

Revista de Administración de Empresas. (1986). 17(12).

Roesch, S. (2003). Quem responde pelo desempenho limitado da produção científica em administração no Brasil? Organizações \& Sociedade, 10(28), 165-167.

Rond, M. de, \& Miller, A. (2005). Publish or perish: bane or boon of academic life? Journal of Management Inquiry, 14(4), 321-329.

Rouse, J. (1992). What are cultural studies of scientific knowledge? Configurations, 1(1), 57-94.

Sahlin-Andersson, K., \& Engwall, L. (2002). The dynamics of management knowledge expansion. In K. Sahlin-Andersson \& L. Engwall (Eds.). The expansion of managment knowledge: carriers, flows, and sources (pp. 277-296). Stanford, CA: Stanford University Press.

Schofer, E. (2004). Cross-national differences in the expansion of science, 1970-1990. Social Forces, 83(1), 215-248.

Schott, T. (1998). Ties between center and periphery in the scientific world-system: accumulation of rewards, dominance and self-reliance in the center. Journal of World-Systems Research, 4(2), 112-144. Retrieved April 20, 2008, from http://jwsr.ucr.edu/archive/vol4/v4n2a3.php

Schwartzman, S. (1991). A space for science: the development of the scientific community in Brazil. University Park, PA: Pennsylvania State University Press.

Schwartzman, S. (1992). Brazil. In B. R. Clark \& G. Neave (Eds.). The encyclopedia of higher education (Vol. 1, pp. 82-92). Oxford: Pergamon Press.

Schwartzman, S., \& Balbachevsky, E. (1997). The academic profession in Brazil. In P. G. Altbach (Ed.). The international academic profession: portraits from 14 countries (pp. 231-280). Princeton, NY: Carnegie Foundation for the Advancement of Teaching.

Seró, C. (2001, Noviembre). La maestría en administración pública de la Universidad de Buenos Aires: contribuciones, paradojas y desafíos. Proceedings of the Congreso Internacional Del CLAD sobre la Reforma Del Estado Y de la Administración Pública, Buenos Aires, Argentina, 6.

Shrum, W., \& Shenhav, Y. (1995). Science and technology in less developed countries. In. S. 
Jasanoff, G. Markle, J. Peterson, \& T. Pinch (Eds.). Handbook of science, technology, and society (pp. 627-651). Newbury Park, CA: Sage.

Stubrin, A. (2003). Configuracion universitaria y política publica de educación superior en la Argentina [Working Paper]. Comisión Nacional de Evaluación y Acreditación Universitaria, Buenos Aires, República Argentina.

Tonelli, M. J., Caldas, M., Lacombe, B. M. B., \& Tinoco, T. (2003). Produção acadêmica em recursos humanos no Brasil: 1991-2000. Revista de Administração de Empresas, 43(1), 106-122.

United Nations. (2006). National accounts main aggregates database, united nations statistical division. Retrieved April 20, 2008, from http://unstats.un.org/unsd/snaama/Introduction.asp

Universidad de Buenos Aires. (2005). Censo docente 04. Retrieved April 20, 2008, from http://www.uba.ar/institucional/censos/Docente2004/censo_docente.pdf

Universidade de São Paulo. (2007). Anuário estatístico 2007. Retrieved April 20, 2008, from http://sistemas.usp.br/anuario/tabelas/T02_11.pdf

Üsdiken, B. (1996). Importing theories of management and organization: the case of Turkish Academia. International Studies of Management and Organization, 26(3), 33-46.

Üsdiken, B., \& Çetin, D. (2001). From betriebswirtschaftslehre to human relations: Turkish management literature before and after the second world war. Business History, 43(2), 90-121.

Wainerman, C. (1999). El rey está desnudo: acerca de la formación de postgrado en ciencias sociales. Boletín Informativo, Consejo de Profesionales en Sociología, 1(5), 4-5.

Whitley, R. (1988). The management sciences and managerial skills. Organization Studies, 9(1), 47-68.

Wood, T., \& Caldas, M. (2002). Adopting imported managerial expertise in developing countries: the Brazilian experience. Academy of Management Executive, 16(2), 18-32.

Wood, T., \& Paes de Paula, A. P. (2003, November). This is not (quite) an MBA! Proceedings of the Business Education and Emerging Market Economies: Trends and Prospects Conference, Atlanta, GA, USA, 7.

Woolgar, S. (1994). Rethinking the dissemination of science and technology [Discussion Paper $\left.\mathrm{N}^{\circ} 44\right]$. Centre for Research into Innovation Culture and Technology, Brunel University, London, UK. 